\title{
Fermented rye with Agaricus subrufescens and mannan-rich hydrolysate based feed additive to modulate post-weaning piglet immune response
}

\author{
Nienke de Groot ${ }^{1,3^{*}} \mathbb{D}$, Fernando Fariñas ${ }^{2}$, Lluís Fabà ${ }^{1}$, Ellen Hambrecht ${ }^{1}$, Carolina G. Cabrera-Gómez ${ }^{3}$,
} Francisco J. Pallares ${ }^{4}$ and Guillermo Ramis ${ }^{3}$

\begin{abstract}
Background: The process of weaning in piglets is often associated with an increased inflammation response in the intestine and compromised intestinal integrity and morphology, favoring a delay in intestinal maturation and a predisposal to diseases. Research has shown the potential of different nutritional strategies to reduce the production of pro-inflammatory cytokines, with the main goal to manipulate health and performance of pigs. Promising examples of nutritional strategies are fungal fermented products and their derivatives which are described to contain several compounds that may play a role in gastrointestinal health and pathogenic bacteria control. Products from Agaricus subrufescens mushroom are reported to contain prophylactic and therapeutic properties including antimicrobial and immunomodulatory properties.
\end{abstract}

Results: This study analysed the post-weaning immune status in intestinal tissue and blood of piglets, with the objective to evaluate the gastrointestinal health and immune modulation response induced by a blend of mannanrich hydrolyzed copra meal and fermented rye with A. subrufescens. Intestinal histomorphology demonstrated a villus height reduction in jejunum and increase in ileum on day 15, while increased villous height in jejunum and ileum on day 30. The results showed that in post-weaning piglets, the feed additive stimulates an immunomodulation effect most evident at 15 days post-weaning, with significant lower expression of cytokines Interferon (IFN) $\gamma$, Interleukin (IL) $1 \mathrm{a}, \mathrm{LL}-1 \beta, \mathrm{LL}-6, \mathrm{IL}-8, \mathrm{LL}-10$ and Transforming Growth Factor (TGF) $\beta$ in jejunum, accompanied with an increase in peripheral blood mononuclear cells (PBMC) cytokine gene expression of IL-1 $\beta, I L-6, I L-8, I L-10, I L-12 p 35$ (IL-12a), IL-12p40 (IL-12 $\beta$ ), Tumor Necrosis Factor (TNF) $\alpha$, IFN- $\alpha$, and TGF- $\beta$. In piglets fed the feed additive, the quantity of Immunoglobulin (Ig) A producing cells in jejunum, ileum was reduced on day 15 and 30 post-weaning, and on day 30 and 45 post-weaning in colon tissue. Natural Killer (NK) cells count in blood were increased on day 15 post-weaning in the piglets fed the feed additive.

Conclusion: This study implies the potential of the blend including mannan-rich hydrolyzed copra meal and fermented rye with A. subrufescens on immune modulation in the intestine of post-weaning piglets.

Keywords: Inflammation, Cytokines, Additive, Intestine, Piglets, Weaning

\footnotetext{
*Correspondence: nienkedgroot@gmail.com

${ }^{1}$ Trouw Nutrition Innovation, Amersfoort $3811 \mathrm{MH}$, The Netherlands

Full list of author information is available at the end of the article
} original author(s) and the source, provide a link to the Creative Commons licence, and indicate if changes were made. The images or other third party material in this article are included in the article's Creative Commons licence, unless indicated otherwise in a credit line to the material. If material is not included in the article's Creative Commons licence and your intended use is not permitted by statutory regulation or exceeds the permitted use, you will need to obtain permission directly from the copyright holder. To view a copy of this licence, visit http://creativecommons.org/licenses/by/4.0/. The Creative Commons Public Domain Dedication waiver (http://creativeco mmons.org/publicdomain/zero/1.0/) applies to the data made available in this article, unless otherwise stated in a credit line to the data. 


\section{Background}

The gastrointestinal tract (GIT) is essential in the maintenance of health. The gut mucosal immune system alone contains more than $10^{12}$ lymphocytes and has a greater concentration of antibodies than other tissues in the body [1]. The intestine main function is the uptake of nutrients while simultaneously form a physical barrier which should prevent toxic compounds and pathogens from crossing the intestinal mucosa and systemic circulation. Two major components of the intestinal barrier are the intestinal epithelium and the gut associated lymphoid tissue (GALT). This tissue has the challenging dual task of selectively absorbing nutrients from the intestinal lumen, while preventing microbial and toxins entry and infection. One of the strategies that the host utilizes to avoid an inflammatory response against the microbiota is to use the intestinal barrier, including the mucous layer and immunoglobulin (Ig) A, an antibody isotype specialized in mucosal protection [2, 3] and produced locally by plasma cells present in the mucosal wall.

Previous research has shown that the process of weaning in piglets is associated with an increased inflammation response in the intestine $[4,5]$, and the potential negative effect of increased expression of inflammation markers on intestinal integrity [6, 7], morphology of intestinal structures such as villous length and crypt depth $[4,8]$ and disruption of the microbiota [9, $10]$, favoring a delay in intestinal maturation and a predisposal to diseases $[11,12]$. Recent research by Pluske et al. [13] has shown the potential of different management measures around weaning such as implementing nutritional strategies to reduce intestinal pathogen load, increasing digestion and preventing production and activity of pro-inflammatory cytokines, all with the main goal to manipulate the immune system of pigs for improving performance, aiming to have an appropriate immune response for each specific circumstance, preventing to maximize the immune response [13]. Furthermore, nutritional strategies can modulate the complex interplay between the immune system and/or inflammatory responses and neuroendocrine mediators such as growth hormone and cortisol, thus having consequences on animal health and performances [14].

Promising examples of nutritional strategies are metabolites derived from edible mushrooms. Fungal fermented products and their derivatives are described to contain several compounds that may play a role in gastrointestinal health and pathogenic bacteria control [15]. Microbial enzymes produced by fungi during fermentation will degrade polysaccharides from feed material into indigestible and bioactive oligosaccharides [16]. Agaricus subrufescens, also known as A. blazei murill and/or the almond mushroom, is an edible mushroom, which grows naturally in Piedade, outside of São Paulo, Brazil. It contains high levels of biological response modulators, such as proteoglycans $[17,18]$ and $\beta$-glucans [19], which are a heterogeneous group of polysaccharides present in cereal grains, fungal cell walls, seaweed, and algae [20]. Products from $A$. subrufescens mushroom are reported to contain prophylactic and therapeutic properties including antimicrobial and immunomodulatory properties $[15,21]$.

The gastro-intestinal immune system is geared towards tolerance, in contrary to the systemic immune system, and responds to intestinal content (microbiota, metabolites, feed components, etc.), and this reaction can lead to tolerance (e.g. for commensal bacteria) or defense reactions [22]. One of the strategies that the host utilizes to avoid an inflammatory response against the microbiota is to use the intestinal barrier, including the mucous layer and immunoglobulin (Ig) A, an antibody isotype specialized in mucosal protection [2, 3]. Production of IgA is controlled by cytokine-producing $\mathrm{T}$ cells within the GALT and by cytokine released from the mucosa $[2,3,23]$. Previous studies report changes in the expression of inflammatory cytokines in the intestine of humans and animals during enteric infection and intestinal inflammatory diseases [24-26]. Both in vitro and in vivo investigations show that uncontrolled production of pro-inflammatory cytokines can influence gut integrity and epithelial functions, including permeability to macromolecules and transport of nutrients and ions [27]. Interactions of immune cell populations, present in the epithelium of the intestine, and other components of the intestinal mucosa are essential in the maintenance of symbiosis with commensals and the defense against pathogens.

From a nutritional perspective, controlling early intestinal inflammation is certainly a challenge in managing post-weaning gut disorders and preventing intestinal inflammation due to pathogenic enteric organisms can be an important pillar to maintain the health of piglets. The objective of this study was to evaluate the gastrointestinal health and immune modulation response induced by a blend of mannan-rich hydrolyzed copra meal and fermented rye with $A$. subrufescens in weaned piglets.

\section{Results}

\section{Growth performance}

Least squares means and standard errors for body weight (BW) and average daily gain (ADG) for control and Fysal $^{\circledR}$ Solute (FS) treatment are given in Table 1. Average daily gain tended to be higher in FS treatment for day 0-15 $(P=0.078)$. There was no statistical evidence for other performance differences between control and treatment group. 
Table 1 Effect of dietary treatment ${ }^{1}$ on performance of weaned piglets at different time points

\begin{tabular}{|c|c|c|c|c|c|}
\hline & Day & Treatment & LSmeans & SEM & $P$-value \\
\hline \multirow[t]{8}{*}{ BW, kg } & \multirow[t]{2}{*}{0} & Control & 5.59 & 0.225 & \multirow[t]{2}{*}{0.705} \\
\hline & & $\mathrm{FS}^{1}$ & 5.97 & 0.178 & \\
\hline & \multirow[t]{2}{*}{15} & Control & 8.84 & 0.761 & \multirow[t]{2}{*}{0.111} \\
\hline & & FS & 10.4 & 0.603 & \\
\hline & \multirow[t]{2}{*}{30} & Control & 14.5 & 1.19 & \multirow[t]{2}{*}{0.467} \\
\hline & & FS & 15.6 & 0.753 & \\
\hline & \multirow[t]{2}{*}{45} & Control & 17.9 & 2.12 & \multirow[t]{2}{*}{0.318} \\
\hline & & FS & 20.7 & 1.84 & \\
\hline \multirow[t]{8}{*}{$A D G, \mathrm{~kg} / \mathrm{d}$} & \multirow[t]{2}{*}{$0-15$} & Control & $0.199^{x}$ & 0.043 & \multirow[t]{2}{*}{0.079} \\
\hline & & $\mathrm{FS}^{1}$ & $0.297^{y}$ & 0.034 & \\
\hline & \multirow[t]{2}{*}{$0-30$} & Control & 0.288 & 0.032 & \multirow[t]{2}{*}{0.402} \\
\hline & & FS & 0.320 & 0.020 & \\
\hline & \multirow[t]{2}{*}{$0-45$} & Control & 0.305 & 0.035 & \multirow[t]{2}{*}{0.605} \\
\hline & & FS & 0.330 & 0.031 & \\
\hline & \multirow[t]{2}{*}{$30-45$} & Control & 0.358 & 0.045 & \multirow[t]{2}{*}{0.409} \\
\hline & & FS & 0.408 & 0.039 & \\
\hline
\end{tabular}

SEM, standard error of the mean; BW, body weight; $A D G$, average daily gain $x, y$ Different superscripts within a column indicate a tendency difference $(P<0.10)$

${ }^{1}$ Dietary treatment $=$ additional Fysal Solute (FS) at $2 \mathrm{~kg} /$ ton

\section{Intestinal histomorphometry}

Data on small intestine villi characteristics are presented in Table 2 and Figs. 1 and 2. The villous length in jejunal tissue was lower on day 15 for FS compared to control $(P<0.05)$. On day 15 in ileal tissue the villous length tended $(P=0.09)$ to be higher in FS compared to control. On day 30 an higher villous length in jejunal tissue $(P<0.05)$ and a tendency in ileal tissue $(P=0.09)$ were observed for FS compared to control. In ileal tissue the $\mathrm{V} / \mathrm{C}$ ratio was higher in FS compared to control on day $30(P<0.05)$.

\section{IgA producing cells in intestinal tissues}

Several differences were observed between control and dietary treatment for various intestinal tissues and time points. Compared to control, the average count of IgA producing cells on day 15 was lower $(P<0.05)$ in piglets fed the FS diet in jejunum and ileum, being not different in colon. On day 30, compared to control, the average count of IgA producing cells was lower $(P<0.05)$ in piglets fed with FS in jejunum, ileum and colon. The average count of IgA producing cells in colon was lower $(P<0.05)$ in piglets fed with FS on day 45 compared to control (Table 3, Fig. 1), with no difference in jejunum and ileum on day 45.

\section{Immunoglobulin concentration in serum}

Comparing the effect of treatment on different immunoglobulin levels per sampling point, on day 45, a higher IgG quantity in blood was found in FS compared to control $(P<0.05)$. No differences were observed for IgE levels on any of the sampling time points. Dietary treatment FS had a higher IgA level in blood compared to control on day $15(P<0.05)$. On day 15 , IgM concentration in blood tended to be higher in FS treatment $(P=0.07)$ compared to control. On day 45 , higher IgM levels were observed in FS compared to control group $(P<0.05$; Table 4$)$.

\section{Cytokine gene expression in tissues}

Several differences for cytokine expression were identified between dietary treatments. On day 15, a lower gene expression was observed for IFN- $\gamma$, IL- $1 \alpha$ and IL-10 $(P<0.05)$ and a tendency $(P<0.10)$ for a lower expression of IL-1 $\beta$, IL- 6 and TNF- $\alpha$ in the jejunum. There were no differences on day 15 in ileum. In colon tissue, expression of IL-10 and IL-12 $\beta$ tended $(P<0.10)$ to be lower in FS compared to control. In PBMC on day 15 , a significantly higher expression of IFN- $\alpha$, IL- $1 \alpha$, IL-6, IL-10, IL-12 $\beta$ and TGF- $\beta$ was shown in FS compared to control. Furthermore, tendencies for higher expression were shown for IL-1 $\beta$, IL-8, IL- $12 \alpha$ and TNF- $\alpha$ in FS treatment compared to control $(P<0.10$; Table 5 and Appendix 1).

On day 30, tendencies were observed for a higher $(P=0.05)$ expression of IFN- $\alpha$ in the jejunum, and for a lower expression $(P=0.05)$ in TGF- $\beta$ in FS treatment compared to control. In the ileum, a tendency indicated a lower expression of IL-10 and IL-12 $\beta(P<0.10)$. In colon, a higher expression of IL-10 $(P<0.05)$ and a tendency for a higher expression in IL- $12 \beta$ in the FS treatment compared to control were observed $(P=0.089)$. In PBMC, a tendency for a higher TGF- $\beta$ expression was observed in FS treatment compared to control $(P=0.07$; Table 5 and Appendix 1$)$.

On day 45 , lower IFN- $\gamma$, IL- $1 \alpha$ and IL-10 expression in the jejunum $(P<0.05)$, higher $(P<0.05)$ IL-8 expression in the ileum, lower $(P<0.05)$ IL-10 expression in colon were observed for FS treatment compared to control. FS tended $(P<0.1)$ to reduce IFN- $\gamma$ and IL-12 $\beta$ expression in colon. Furthermore, in PBMC, IL-1 $\beta$ expression was $(P<0.05)$ reduced by FS compared to control (Table 5).

Comparing gene expression of cytokines in jejunum, ileum, colon and PBMC over the three time points, it was observed that FS treatment reduced local tissue gene 
Table 2 Effect of dietary treatment ${ }^{1}$ on intestinal histomorphometry measurements in tissue of piglets at different time points

\begin{tabular}{|c|c|c|c|c|c|c|}
\hline Day & Tissue & Parameter & Treatment & LSmeans & SEM & $P$-value \\
\hline \multirow[t]{12}{*}{15} & Jejunum & Villous length, $\mu \mathrm{m}$ & Control & $492^{\mathrm{a}}$ & 16.8 & 0.035 \\
\hline & & & $\mathrm{FS}^{1}$ & $438^{b}$ & 16.8 & \\
\hline & & Crypt depth, $\mu \mathrm{m}$ & Control & 292 & 13.7 & 0.264 \\
\hline & & & FS & 317 & 16.0 & \\
\hline & & V/C ratio ${ }^{2}$ & Control & 1.36 & 0.169 & 0.358 \\
\hline & & & FS & 1.13 & 0.187 & \\
\hline & Ileum & Villous length, $\mu \mathrm{m}$ & Control & $414^{x}$ & 15.7 & 0.093 \\
\hline & & & FS & $452^{y}$ & 14.9 & \\
\hline & & Crypt depth, $\mu \mathrm{m}$ & Control & 258 & 17.0 & 0.116 \\
\hline & & & FS & 297 & 17.0 & \\
\hline & & V/C ratio & Control & 1.50 & 0.104 & 0.657 \\
\hline & & & FS & 1.57 & 0.104 & \\
\hline \multirow[t]{12}{*}{30} & Jejunum & Villous length, $\mu \mathrm{m}$ & Control & $447^{\mathrm{a}}$ & 16.4 & 0.002 \\
\hline & & & FS & $519^{b}$ & 10.6 & \\
\hline & & Crypt depth, $\mu \mathrm{m}$ & Control & 319 & 26.8 & 0.168 \\
\hline & & & FS & 363 & 13.4 & \\
\hline & & V/C ratio & Control & 1.02 & 0.186 & 0.431 \\
\hline & & & FS & 0.84 & 0.137 & \\
\hline & Ileum & Villous length, $\mu \mathrm{m}$ & Control & $403^{x}$ & 26.6 & 0.093 \\
\hline & & & FS & $459^{y}$ & 16.0 & \\
\hline & & Crypt depth, $\mu \mathrm{m}$ & Control & 354 & 29.8 & 0.356 \\
\hline & & & FS & 320 & 18.0 & \\
\hline & & V/C ratio & Control & $1.18^{\mathrm{a}}$ & 0.100 & 0.035 \\
\hline & & & FS & $1.46^{\mathrm{b}}$ & 0.068 & \\
\hline \multirow[t]{12}{*}{45} & Jejunum & Villous length, $\mu \mathrm{m}$ & Control & 516 & 25.4 & 0.969 \\
\hline & & & FS & 515 & 22.8 & \\
\hline & & Crypt depth, $\mu \mathrm{m}$ & Control & 317 & 22.1 & 0.227 \\
\hline & & & FS & 354 & 19.8 & \\
\hline & & V/C ratio & Control & 0.930 & 0.078 & 0.287 \\
\hline & & & FS & 0.814 & 0.070 & \\
\hline & Ileum & Villous length, $\mu \mathrm{m}$ & Control & 452 & 27.2 & 0.234 \\
\hline & & & FS & 497 & 24.3 & \\
\hline & & Crypt depth, $\mu \mathrm{m}$ & Control & 324 & 16.3 & 0.428 \\
\hline & & & FS & 305 & 17.3 & \\
\hline & & V/C ratio & Control & 1.49 & 0.100 & 0.717 \\
\hline & & & FS & 1.55 & 0.100 & \\
\hline
\end{tabular}

SEM, standard error of the mean

a,b Different superscripts within a column indicate a significant difference $(P<0.05)$

$x, y$ Different superscripts within a column indicate a tendency difference $(P<0.1)$

${ }^{1}$ Dietary treatment $=$ additional Fysal Solute (FS) at $2 \mathrm{~kg} / \mathrm{ton}$

${ }^{2} \mathrm{~V} / \mathrm{C}$ ratio $=$ Villous length $(\mu \mathrm{m})$ divided by Crypt depth $(\mu \mathrm{m})$

expressions of several cytokines, mainly on day 15 and 45 , and increases gene expression in PBMC mainly on day 15 (Table 5 and Appendix 1).

\section{Levels of cytokines and lymphocytes in blood}

Differences between control and FS fed pigs in the concentration of IL-10 in blood are presented in Table 6. Pigs fed FS show a lower level on day 15 compared to control $(P<0.05)$, and a tendency for reduction on day $30(P=0.08$; Table 6$)$. No differences were observed in 

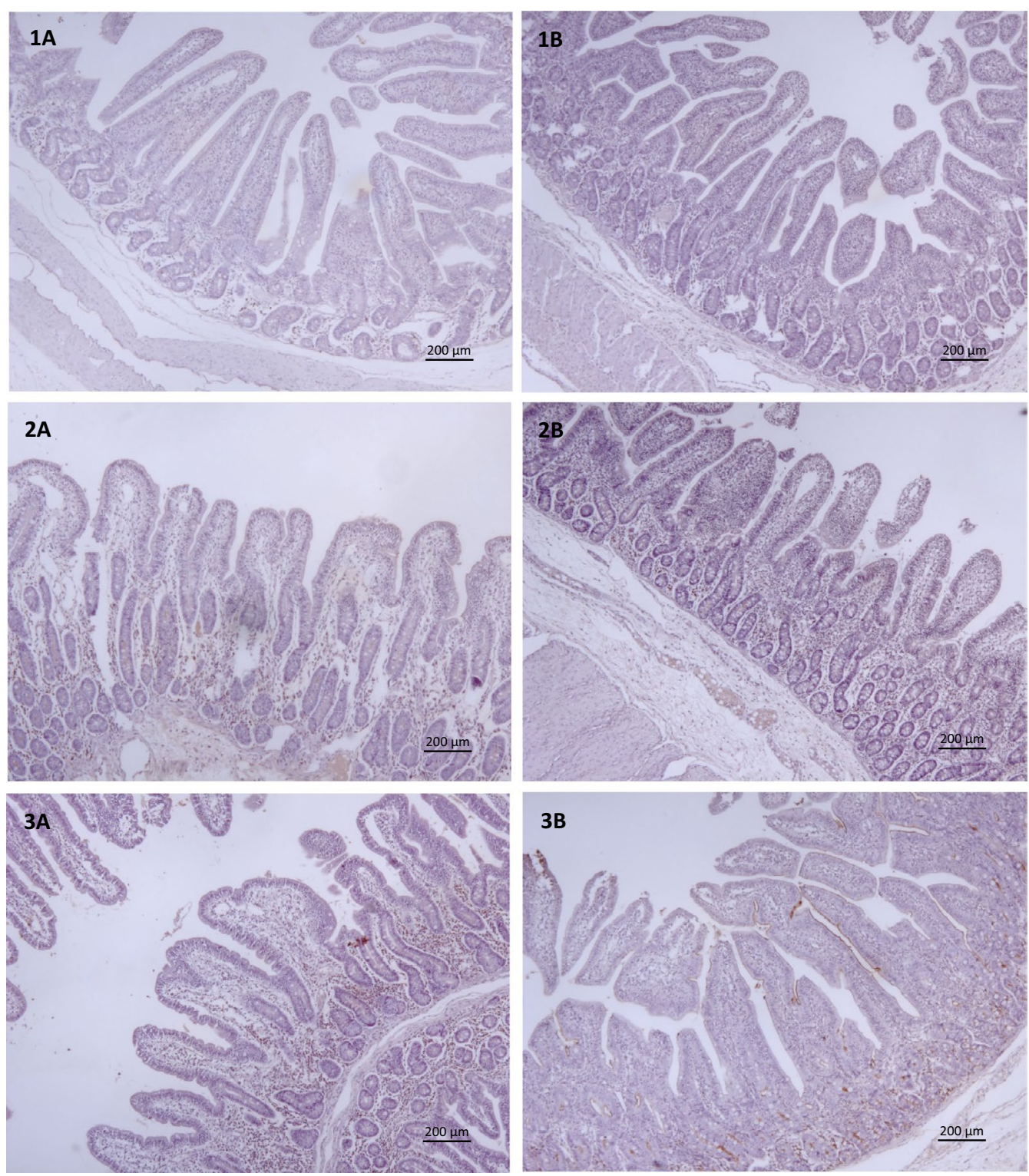

Fig. 1 Immunohistochemical expression of IgA in the jejunum of animals from all experimental groups. The same sections were used, at different magnifications for histomorphometry and count of IgA producing cells. 1A: Control day 15, 1B: FS day 15, 2A: Control day 30, 2B: FS day 30, 3A Control day 45, 3B FS day 45

level of IFN- $\gamma$ and the IFN- $\gamma / \mathrm{IL}-10$ ratio between control and FS dietary treatments.

On day 15, level of NK cells was higher in FS compared to control $(P<0.05)$. On day 45 , a lower level of $B$ cells was observed in FS compared to control $(P<0.05)$. Th lymphocyte level tended to be lower on day 30 in pigs fed FS compared to control $(P=0.08)$. TCD3, a count for total T cells, level tended to be lower on day 15 in FS compared to control $(P=0.08)$. On day 45 , CD4-CD8-lymphocytes were higher $(P<0.05)$, while $\mathrm{CD} 4+\mathrm{CD} 8+$ levels were observed to be lower in FS compared to control $(P=0.07)$ (Table 7).

\section{Discussion}

Weaning-associated intestinal inflammation occurs in piglets $[4,5]$. Determining nutritional strategies to prevent intestinal inflammation due to pathogenic enteric organisms can be an important pillar to maintain health status of animals. The present study provides evidence in immune modulation response induced by a blend of 

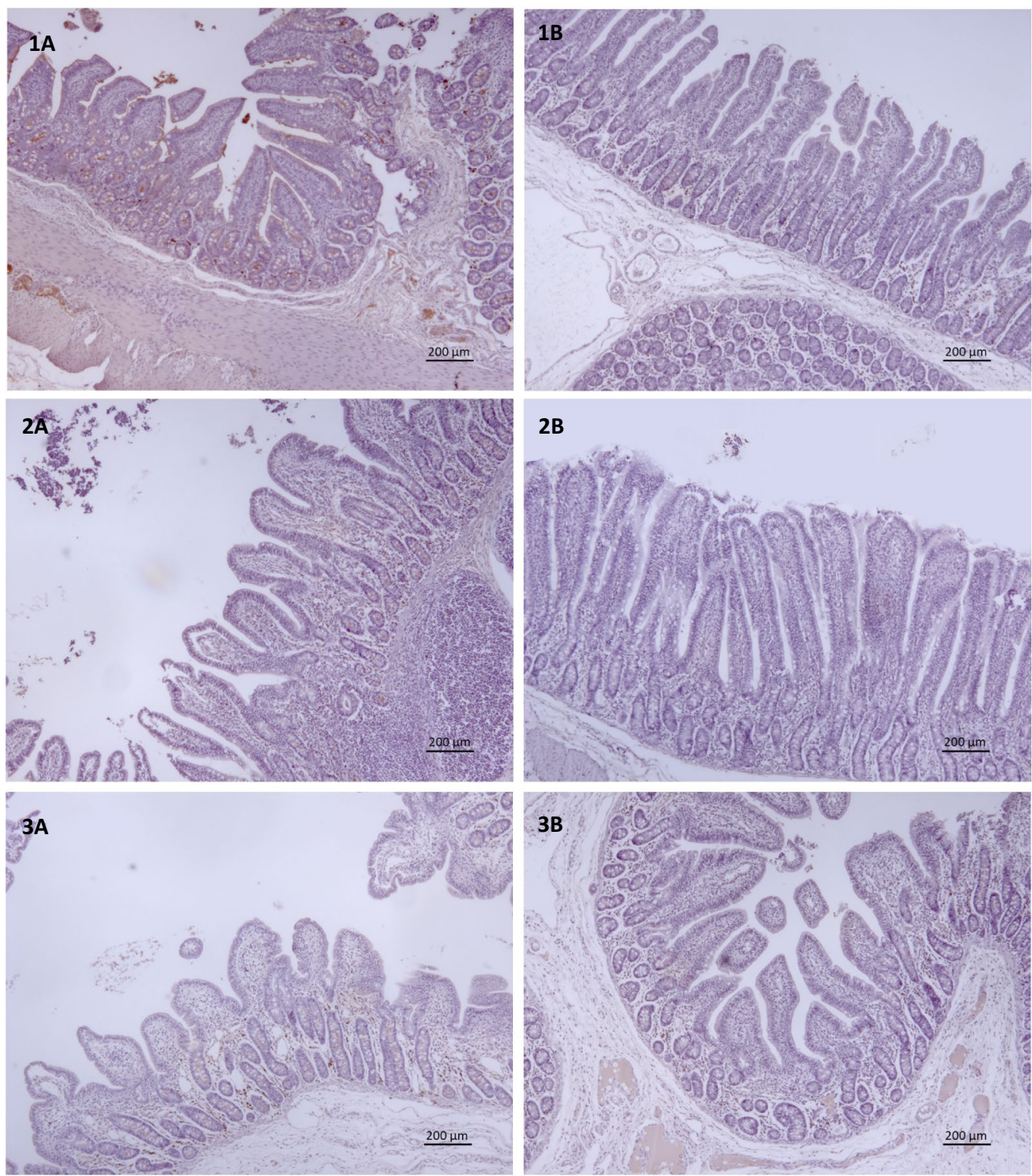

Fig. 2 Immunohistochemical expression of $\lg A$ in the ileum of animals from all experimental groups. The same sections were used, at different magnifications for histomorphometry and count of IgA producing cells. 1A: Control day 15, 1B: FS day 15, 2A: Control day 30, 2B: FS day 30, $\mathbf{3 A}$ Control day 45, 3B FS day 45

mannan-rich hydrolyzed copra meal and fermented rye with A. subrufescens in piglets post-weaning.

The primary focus of the current study was on piglet immunity and intestinal health while due to design obvious reasons, the performance was secondary. Nonetheless, a tendency for improved ADG was observed in piglets fed FS during the first 15 days which suggests a potential benefit of FS effects on immunity and intestinal morphometry improving growth performance. Furthermore, throughout the study, no piglets developed diarrhea or other disease related clinical signs, indicating that this study was done in a healthy environment, authors suggest to repeat a similar study under higher disease pressure conditions.

There is little research assessing such fungi origin feed additive (or similar components) effect on pig performance. A report by the Danish National Committee for Pig Production described the effect of $0.1 \%$ A. subrufescens extract added to weaner feed, and found no differences in diarrhea or mortality, but an $11 \%$ increase in productivity in the supplemented group [28]. In a Chinese study, the use of $A$. subrufescens improved the growth 
Table 3 Effects of dietary treatment ${ }^{1}$ on Immunoglobulin A producing cells ${ }^{2}$ in tissue of piglets at different time points

\begin{tabular}{|c|c|c|c|c|c|}
\hline Tissue & Day & Treatment & LSmeans & SEM & $P$-value \\
\hline \multirow[t]{6}{*}{ Jejunum } & 15 & Control & $13.6^{\mathrm{a}}$ & 1.05 & $<0.001$ \\
\hline & & FS & $7.28^{\mathrm{b}}$ & 1.00 & \\
\hline & 30 & Control & $23.0^{\mathrm{a}}$ & 1.60 & 0.009 \\
\hline & & FS & $17.3^{b}$ & 1.03 & \\
\hline & 45 & Control & 26.0 & 3.00 & 0.544 \\
\hline & & FS & 23.5 & 2.72 & \\
\hline \multirow[t]{6}{*}{ Ileum } & 15 & Control & $11.8^{\mathrm{a}}$ & 0.896 & 0.001 \\
\hline & & FS & $6.62^{b}$ & 0.850 & \\
\hline & 30 & Control & $20.2^{\mathrm{a}}$ & 1.44 & 0.002 \\
\hline & & FS & $13.4^{\mathrm{b}}$ & 1.02 & \\
\hline & 45 & Control & 18.7 & 2.16 & 0.429 \\
\hline & & FS & 16.4 & 1.95 & \\
\hline \multirow[t]{6}{*}{ Colon } & 15 & Control & 11.3 & 1.00 & 0.130 \\
\hline & & FS & 8.98 & 1.06 & \\
\hline & 30 & Control & $19.7^{\mathrm{a}}$ & 1.96 & 0.001 \\
\hline & & FS & $15.6^{b}$ & 0.91 & \\
\hline & 45 & Control & $23.0^{\mathrm{a}}$ & 1.31 & 0.012 \\
\hline & & FS & $17.9^{\mathrm{b}}$ & 1.24 & \\
\hline
\end{tabular}

SEM = standard error of the mean

$\mathrm{a}, \mathrm{b}$ Different superscripts within a column indicate a significant difference $(P<0.05)$

${ }^{1}$ Dietary treatment $=$ additional Fysal Solute (FS) at $2 \mathrm{~kg} / \mathrm{ton}$

${ }^{2}$ Immunolabeled cells were counted in 10 non-overlapping consecutive high magnification fields of $25,000 \mu \mathrm{m}$

performance of weaned piglets, with a reduced feed conversion rate [29]. Next to performance improvement, the researchers found that feeding soluble metabolites of $A$. subrufescens stimulated intestinal villous development, which was also found in more recent research, where the supplementation of $A$. subrufescens increased the villous height and the ratio of villous height/crypt depth of small intestine in mice [30]. These results imply that certain mycelial metabolites of $A$. subrufescens might be important in enhancing villous development, which might consequently enhance the absorption function of intestine. The use of FS in current study lowered villous height on day 15 in jejunum, while villous height in ileum on that same time point was higher, and higher villous height was seen on day 30 both in jejunum as in ileum. Peculiar about these results was that the lower villous height on day 15 in jejunum coincides with a tendency for improvement in growth performance. In fact, the villous height, crypt depth and their ratio in the small intestine are indexes to determine the capacity of intestinal absorption [31] and usually associated with an improvement in growth performance [32]. Nonetheless, there is also evidence that in germ-free animals a slower turnover rate of intestinal epithelial cells resulted in longer villi [33]. A
Table 4 Effects of dietary treatment ${ }^{1}$ on immunoglobulin concentration in serum of piglets at different time points

\begin{tabular}{|c|c|c|c|c|c|}
\hline Immunoglobulin & day & Treatment & LS means & SEM & $P$-value \\
\hline \multirow[t]{6}{*}{$\lg G(\mathrm{mg} / \mathrm{mL})$} & 15 & Control & 5.89 & 0.829 & \\
\hline & & FS & 6.45 & 0.586 & 0.595 \\
\hline & 30 & Control & 6.74 & 0.554 & \\
\hline & & FS & 7.65 & 0.429 & 0.243 \\
\hline & 45 & Control & $7.67^{\mathrm{a}}$ & 0.785 & \\
\hline & & FS & $9.94^{b}$ & 0.453 & 0.047 \\
\hline \multirow[t]{6}{*}{$\lg E(n g / m L)$} & 15 & Control & 22.4 & 1.73 & \\
\hline & & FS & 25.0 & 1.41 & 0.277 \\
\hline & 30 & Control & 22.0 & 4.36 & \\
\hline & & FS & 31.7 & 3.08 & 0.110 \\
\hline & 45 & Control & 25.6 & 5.00 & \\
\hline & & FS & 21.0 & 2.67 & 0.443 \\
\hline \multirow[t]{6}{*}{$\lg A(u g / m L)$} & 15 & Control & $72.4^{\mathrm{a}}$ & 7.66 & \\
\hline & & FS & $101^{b}$ & 6.85 & 0.026 \\
\hline & 30 & Control & 97.1 & 8.87 & \\
\hline & & FS & 107 & 6.27 & 0.371 \\
\hline & 45 & Control & 108 & 41.2 & \\
\hline & & FS & 106 & 22.0 & 0.964 \\
\hline \multirow[t]{6}{*}{$\lg M(\mathrm{ug} / \mathrm{mL})$} & 15 & Control & $62.3^{x}$ & 21.3 & \\
\hline & & FS & $119^{y}$ & 15.1 & 0.066 \\
\hline & 30 & Control & 114 & 17.5 & \\
\hline & & FS & 153 & 12.3 & 0.110 \\
\hline & 45 & Control & $111^{\mathrm{a}}$ & 11.5 & \\
\hline & & FS & $151^{b}$ & 6.15 & 0.019 \\
\hline
\end{tabular}

SEM, standard error of the mean

$a, b$ Different superscripts within a column indicate a significant difference $(P<0.05)$

${ }^{x, y}$ Different superscripts within a column indicate a trend difference $(P<0.10)$

${ }^{1}$ Dietary treatment $=$ additional Fysal Solute (FS) at $2 \mathrm{~kg} /$ ton

slower turnover is seen in neonatal pigs, with an epithelial cell turnover of 7 to 10 days compared to a 2- to 3-day turnover when pigs are 3 weeks of age [34]. Extensively studied are the effects of weaning age on intestinal morphology in the piglets, where early weaning causes villous shortening [35-37]. Therefore, further studies may be required to clarify the mechanism of this improvement by FS on intestinal integrity and growth performance, in different commercial practices such as varying age of weaning genetics, which is known to influence the immune system in pigs [38-40].

The quantity of IgA producing cells in jejunum and ileum on days 15 and 30 and in colon on days 30 and 45 was reduced in piglets fed FS. A potential explanation for this reduction in IgA producing cells could be a lower stimulation by antigens in the pigs intestine. Antigens stimulate mucosal plasma cells to secrete IgA, causing a response in mesenteric lymph nodes, which increases the number of IgA expressing cells [3]. Reduced intestinal 
Table 5 Effects of dietary treatment ${ }^{1}$ on cytokine expression in tissues of piglets at different time points

\begin{tabular}{|c|c|c|c|c|c|c|c|c|c|c|c|c|}
\hline Day & Tissue & IFN-a & IFN- $\gamma$ & IL-1a & $\mathrm{IL}-1 \beta$ & IL-6 & IL-8 & IL-10 & $\mathrm{IL}-12 a$ & $\mathrm{IL}-12 \beta$ & TNF- $a$ & TGF- $\beta$ \\
\hline \multirow[t]{4}{*}{15} & Jejunum & & $<^{*}$ & $<*$ & $<\wedge$ & $<\wedge$ & & $<*$ & & & $<\wedge$ & \\
\hline & Ileum & & & & & & & & & & & \\
\hline & Colon & & & & & & & $<\wedge$ & & $<\wedge$ & & \\
\hline & PBMC & $>^{*}$ & & $>^{*}$ & $>\wedge$ & $>^{*}$ & $>\wedge$ & $>^{*}$ & $>^{*}$ & $>^{*}$ & $>\wedge$ & $>^{*}$ \\
\hline \multirow[t]{4}{*}{30} & Jejunum & $>\wedge$ & & & & & & & & & & $<\wedge$ \\
\hline & Ileum & & & & & & & $<\wedge$ & & & & \\
\hline & Colon & & & & & & & $>^{*}$ & & $>\wedge$ & & \\
\hline & PBMC & & & & & & & & & & & $>\wedge$ \\
\hline \multirow[t]{4}{*}{45} & Jejunum & & $<^{*}$ & $<^{*}$ & & & & $<^{*}$ & & & & \\
\hline & Ileum & & & & & & $>^{*}$ & & & & & \\
\hline & Colon & & $<\wedge$ & & & & & $<^{*}$ & & $<\wedge$ & & \\
\hline & PBMC & & & & $<^{*}$ & & & & & & & \\
\hline
\end{tabular}

$\left.{ }^{*}\right)$ Significant $(P<0.05)$ and $(\wedge)$ tendency $(P<0.1)$ upregulation $(>)$ or downregulation $(<)$ of cytokine mRNA levels of FS compared to control

${ }^{1}$ Dietary treatment $=$ additional Fysal Solute (FS) at $2 \mathrm{~kg} /$ ton

Table 6 Effects of dietary treatment ${ }^{1}$ on cytokine IFN- $\gamma$ and IL-10 concentration and their ratio in blood of piglets at different time points

\begin{tabular}{|c|c|c|c|c|c|}
\hline Day & Parameter & Treatment & LSmeans & SEM & $P$-value \\
\hline \multirow[t]{6}{*}{15} & IFN-,$- p g / m L$ & Control & 7.55 & 2.91 & 0.189 \\
\hline & & FS & 12.9 & 2.38 & \\
\hline & IL-10, pg/mL & Control & $11.9^{\mathrm{a}}$ & 2.42 & 0.028 \\
\hline & & FS & $3.53^{b}$ & 1.98 & \\
\hline & Ratio IFN- $\gamma / \mathrm{IL}-10$ & Control & 0.823 & 1.27 & 0.041 \\
\hline & & FS & 5.08 & 1.14 & \\
\hline \multirow[t]{6}{*}{30} & IFN- $\gamma, \mathrm{pg} / \mathrm{mL}$ & Control & 4.48 & 0.816 & 0.377 \\
\hline & & FS & 3.54 & 0.577 & \\
\hline & IL-10, pg/mL & Control & $51.3^{x}$ & 13.5 & 0.080 \\
\hline & & FS & $17.6^{y}$ & 9.52 & \\
\hline & Ratio IFN- $\gamma / \mathrm{IL}-10$ & Control & 0.207 & 0.687 & 0.511 \\
\hline & & FS & 0.789 & 0.485 & \\
\hline \multirow[t]{6}{*}{45} & IFN- $\gamma, \mathrm{pg} / \mathrm{mL}$ & Control & 3.26 & 1.34 & 0.648 \\
\hline & & FS & 3.99 & 0.720 & \\
\hline & IL-10, pg/mL & Control & 6.46 & 2.28 & 0.934 \\
\hline & & FS & 6.24 & 1.22 & \\
\hline & Ratio IFN- $\gamma / \mathrm{IL}-10$ & Control & 0.479 & 0.189 & 0.416 \\
\hline & & FS & 0.801 & 0.003 & \\
\hline
\end{tabular}

SEM, standard error of the mean

$\mathrm{a}, \mathrm{b}$ Different superscripts within a column indicate a significant difference $(P<0.05)$

${ }^{x, y}$ Different superscripts within a row indicate a tendency difference $(P<0.1)$

${ }^{1}$ Dietary treatment $=$ additional Fysal Solute (FS) at $2 \mathrm{~kg} /$ ton

IgA producing cells in piglets fed FS coincided with elevated IgA and IgM levels in serum on day 15. It is generally accepted that, after antigenic stimulation in the Peyer's patches, IgA + lymphoblasts migrate through the lymph and blood circulation to the lamina propria of the intestine. In the current study it could be hypothesized that the lack of antigenic stimulation in the intestine of piglets fed FS not only reduces the response for increasing number of IgA producing cells in the intestinal tissue but also prevents migration of IgA cells towards the lamina propia in the intestine, potentially explaining the higher levels of IgA in the blood of piglets fed FS. Further research is needed to prove this hypothesis, where the focus should be combining this work with extensive microbiota analysis. Previous research performed in piglets has shown a significant decrease in piglet's plasma IgG concentrations immediately after weaning, which coincides with the depletion of maternal immunity $[5,7$, 41]. In current study, piglets receiving FS had an increase in serum IgG quantity at day 45. Previous in vivo results have shown the extract of the mushroom exhibited a significantly increased serum IgG level, T-cell population and phagocytic activity [42] in mice.

Analyses on lymphocyte concentration in blood demonstrated an increase in NK cells when feeding FS component. Interestingly, previous studies with the same mushroom fraction also enhanced the activity of NK cells in spleen [43, 44]. Yuminamochi et al. [45] demonstrated that powdered dried fruiting bodies and hemicellulasedigested component of $A$. subrufescens augmented NK cells activation through IL-12 mediated IFN- $\gamma$ production. $\beta$-glucans and proteoglucans are known to be potent stimulators of macrophages [46-48], polymorph nuclear neutrophils (PMN) [49] and Natural Killer (NK) cells [50]. In current study, besides an increase in amount of NK cells, lower amounts of T and B cells were observed in the treatment group at different timepoints. This can be of interest due to the previously reported downregulation of $\mathrm{T}$ helper pro-inflammatory pathways by $\beta-1,4$ 
Table 7 Effects of dietary treatment ${ }^{1}$ on lymphocytes quantification ${ }^{2}$ in blood of piglets at different time points

\begin{tabular}{|c|c|c|c|c|c|}
\hline Lymphocyte $^{3}$ & Day & Treatment & LSMeans & SEM & $P$-value \\
\hline \multirow[t]{6}{*}{ NK } & 15 & Control & $27.3^{\mathrm{a}}$ & 1.48 & 0.035 \\
\hline & & FS & $32.2^{b}$ & 1.56 & \\
\hline & 30 & Control & 23.3 & 4.737 & 0.278 \\
\hline & & FS & 29.3 & 3.09 & \\
\hline & 45 & Control & 36.8 & 2.09 & 0.127 \\
\hline & & FS & 32.4 & 1.78 & \\
\hline \multirow[t]{6}{*}{ B } & 15 & Control & 11.3 & 2.01 & 0.740 \\
\hline & & FS & 10.3 & 1.91 & \\
\hline & 30 & Control & 12.3 & 1.45 & 0.142 \\
\hline & & FS & 9.55 & 1.03 & \\
\hline & 45 & Control & $10.2^{x}$ & 0.917 & 0.069 \\
\hline & & FS & $7.85^{y}$ & 0.829 & \\
\hline \multirow[t]{6}{*}{ TCD 4 (Th) } & 15 & Control & 25.3 & 1.86 & 0.555 \\
\hline & & FS & 23.7 & 1.86 & \\
\hline & 30 & Control & $33.8^{x}$ & 2.81 & 0.081 \\
\hline & & FS & $27.4^{y}$ & 1.99 & \\
\hline & 45 & Control & 27.1 & 1.25 & 0.849 \\
\hline & & FS & 27.4 & 1.13 & \\
\hline \multirow[t]{6}{*}{ T CD8 (Tc) } & 15 & Control & 17.9 & 2.02 & 0.879 \\
\hline & & FS & 18.4 & 2.02 & \\
\hline & 30 & Control & 20.9 & 2.04 & 0.944 \\
\hline & & FS & 20.6 & 1.70 & \\
\hline & 45 & Control & 15.7 & 1.92 & 0.999 \\
\hline & & FS & 15.7 & 1.64 & \\
\hline \multirow[t]{6}{*}{ TCD3 } & 15 & Control & $62.3^{x}$ & 3.61 & 0.084 \\
\hline & & FS & $53.1^{y}$ & 3.42 & \\
\hline & 30 & Control & 55.7 & 3.56 & 0.192 \\
\hline & & FS & 49.6 & 2.72 & \\
\hline & 45 & Control & 50.5 & 2.74 & 0.991 \\
\hline & & FS & 50.5 & 2.49 & \\
\hline
\end{tabular}

SEM, standard error of the mean

${ }^{\mathrm{a}, \mathrm{b}}$ Different superscripts within a column indicate a significant difference $(P<0.05)$

${ }^{x, y}$ different superscripts within a column indicate a tendency difference $(P<0.1)$

${ }^{1}$ Dietary treatment $=$ additional Fysal ${ }^{\circledR}$ Solute (FS) at $2 \mathrm{~kg} /$ ton

${ }^{2}$ Measurement unit for all lymphocytes is amount of cells $/ \mu \mathrm{L}$

${ }^{3} \mathrm{NK}=$ lymphocytes Natural killer (CD45 + CD3-CD16+CD56+), $B=$ lymphocytes $B(C D 45+C D 21+), T C D 4 T h=$ lymphocytes $T$ helper $(C D 45+C D 3+C D 4 a+), T C D 8 T c=$ lymphocytes T cytotoxic $(\mathrm{CD} 45+\mathrm{CD} 3+\mathrm{CD} 8 \mathrm{a}+), \mathrm{TCD} 3=$ lymphocytes $\mathrm{T}(\mathrm{CD} 45+\mathrm{CD} 3 \mathrm{e}+)$

mannobiose in a colitis pig model, induced by dextran sodium sulfate at $1.25 \mathrm{~g} / \mathrm{kg} \mathrm{BW} /$ day, which maintained intestinal permeability and histological morphology [51]. The immunomodulatory properties of different $\beta$-glucans have been demonstrated in vitro $[21,52]$. Recent studies in pigs have shown modulation of mucosal immunity by binding of polysaccharides to specific receptors of immune cells. This could provide beneficial effects on animal health and resistance to disease, since blocking fimbriae of pathogenic bacteria prevents their adhesion to the mucous epithelium which may prevent or eliminate infection [53]. A challenge study induced by F18 Escherichia coli $\left(10^{10} \mathrm{cfu} / 3 \mathrm{ml}\right.$ for 3 days $)$ demonstrated a reduction in diarrhea, potentially caused by a reduced gut permeability, together with a reduction in mRNA expression of IL-1 $\beta$, IL-6, and TNF- $\alpha$ in ileal mucosa of piglets receiving $\beta$-glucans in their diets [54].

Current study shows, that next to a reduction in IgA producing cells in the intestine, lower intestinal cytokine expression was seen in piglets fed FS, mainly in expression of IFN- $\gamma$, IL- $1 \alpha$ and IL-1 $\beta$, IL- 6 , IL-10 and TNF- $\alpha$. Previous research has shown that challenging conditions can increase the gene expression of proinflammatory cytokines, such as the process of weaning or bacterial or infectious challenges. Studies provide evidence of cytokine regulation by weaning process with increased production of pro-inflammatory cytokines post-weaning $[4,5,55]$. Production of intestinal mucosal IgA is controlled by cytokine-producing $\mathrm{T}$ cells within the GALT and by cytokines released from the mucosa. Within the GALT, the $\mathrm{Th}_{1}$ cytokines, IFN- $\gamma$ and TNF- $\beta$, downregulate IgA production, whereas the $\mathrm{Th}_{2}$ cytokines, IL-4, IL-5, IL-6, and IL-10, upregulate IgA production $[56,57]$. Several cytokines, such as TGF- $\beta$, IL- $1 \alpha$, and IL- 6 are constitutively expressed by the intestinal epithelium and may play a role in the normal influx of immune cells into the mucosa, in the growth of epithelial cells and in homeostasis [58]. Resulting from a study performed in humans, other cytokines, such as IL- 8, IL- $1 \beta$ and TNF- $\alpha$ are also expressed by normal epithelial cells but are upregulated in response to microbial infection [59]. The reduction in IgA secretory cells, combined with lower expression of cytokines in the intestinal mucosa could implicate a lower stimulated immune system, implicating a potential immunomodulating effect of FS.

This potential mode of action of fungal fermented products and their derivatives has been previously reported, where they are described to contain several compounds that may play a role in gastrointestinal health and pathogenic bacteria control [15]. Promising examples are metabolites derived from edible mushrooms. Products from the A. subrufescens are reported to contain prophylactic and therapeutic properties, including antimicrobial and immunomodulatory properties [15, 21]. A. subrufescens, also known as A. blazei murill, is an edible mushroom, which grows naturally in Piedade, outside of São Paulo, Brazil. It contains high levels of biological response modulators, such as proteoglycans $[17,18]$ and $\beta$-glucans [19], which are a heterogeneous group of polysaccharides present in cereal grains, fungal cell walls, seaweed, and algae [20]. Microbial enzymes produced by 
fungi during fermentation will degrade polysaccharides from feed material into indigestible and bioactive oligosaccharides [16].

Many successful enteric organisms have developed strategies to resist displacement from the epithelium via the development of anchoring adhesive fimbriae (pili) [60]. Approaches to masking these attachment sites from pathogenic bacteria include the feeding of competing carbohydrates (oligosaccharides) that inhibit attachment of certain bacteria to the epithelium [61]. Adhesins from some pathogenic Enterobacteriaceae are known to show binding affinity to distinct indigestible oligosaccharides. Wang et al. [62] demonstrated such affinity for suitable oligosaccharides, i.e., d-mannose showed between 20 and $60 \%$ inhibition of bacterial adhesion (E. coli, Vibrio cholerae, Campylobacter jejuni, and Salmonella typhimurium) to host glycans from HT-29 cells (54). For example, addition of $2-5 \%$ D-mannose to broiler diets reduced the excretion and colonization of S. enterica var. typhimurium [63], while the use of a mannan oligosaccharide has been reported to reduce the concentration of caecal coliforms and S. enterica var. typhimurium and $S$. dublin in chicks $[60,64]$. A recent study demonstrated the effect of in vitro binding of FS, a blend of mannan-rich hydrolyzed copra meal, containing levels of mannobiose, and a fungal fermented rye with A. subrufescens, to $S$. enterica serovars typhimurium and enteritidis. In vivo results demonstrated that feeding those components to nursery pigs reduced the peak and average S. typhimurium shedding compared with control [65]. Based on the recent data with FS and its components, in current study the potential beneficial effect of FS against pathogenic bacteria by its binding capacity could have lowered the number of pathogenic bacteria in the lumen, or shifting microbiota reducing an immunological response initiated by the dendritic cells in the intestine. This can in turn result in a lower amount of IgA producing cells and a lower gene expression of cytokines such as IFN- $\gamma$, IL-1, IL-6, IL-10 and, IL-12 and TNF- $\alpha$ in the intestine. However, current study lacks data on the response of the intestinal microbiota to feeding component FS, therefore the exact mode of action of the lower intestinal inflammation response remains to be clarified.

Previous research done using the FS component in combination with organic acids indicated the potential in modifying the intestinal microbiota, with a higher abundance of Lactobacillus spp and a lower abundance of Clostridium spp. after a $S$. typhimurium challenge in post-weaning piglets [66]. Furthermore, previous work in grower pigs showed that fed a dietary supplementation of A. bisporus (white button) mushrooms positively affected the composition of the fecal and proximal colon microbiota by promoting the abundance of Ruminococcaceae and
Lachnospiracea families [67]. These families are known for degradation of complex plant material (cellulose and hemicellulose) in the mammalian gut and are considered as beneficial given their production of butyrate [68]. The A. bisporus mushrooms fed to pigs did not affect growth rate, intestinal permeability or systemic and localized activation of mononuclear cells [67]. However, an antiinflammatory effect was observed in LPS-stimulated alveolar macrophages with a significant reduction in IL-1 $\beta$ gene expression and cytokine production reflected in a lower activation of IL-1-signaling in pigs fed $A$. bisporus mushrooms.

Current study showed that reduced intestinal cytokine gene expression coincided with elevated cytokine gene expression in PBMC. This is in agreement with previous research where the use of $A$. subrufescens is shown to stimulate cytokine production in PBMC, such as interleukin-12 (IL-12) [43], or interferon- $\gamma$ (IFN- $\gamma$ ) [45]. Furthermore, the $\beta-1,6-\mathrm{d}$-glucan fraction extracted from $A$. subrufescens induces IFN- $\gamma$ production and can partially reverse the production of IL-10 [69], the latter is in agreement with results of current study. A. subrufescens fraction had been shown to induce macrophages to secrete (TNF- $\alpha$ ), (IL)-8 and nitric oxide (NO) in an in vitro test [70]. Research in human medicine showed $A$. subrufescens extract to promote anti-inflammatory effects without side effects. Like in current study, pro-inflammatory cytokines (IL-1 $\beta$ and IL-6) and chemokine (IL-8) were downregulated, and this was demonstrated ex vivo with heparinized blood of exposed Colitis Ulcerosa, Crohn's Disease and normal patients [71]. These relatively common human diseases are characterized and a consequence of deficiency or enhanced activation of cytokine pathways, which promotes the breakdown of intestinal homeostasis [72, 73]. In pigs, more research is needed in this area. However, the reported post-weaning intestinal upregulation of pro-inflammatory cytokine production $[4,5]$ demonstrates the potential of implementing nutritional strategies as shown in current study, with the aim to manipulate the immune system of pigs and reduce the immune response.

\section{Conclusion}

In post-weaning piglets, feeding component FS, a blend of mannan-rich hydrolyzed copra meal and fermented rye with $A$. subrufescens, stimulates an immune modulation effect most evident at 15 days post-weaning. The effect includes a reduction of local intestinal inflammatory response, with emphasis in jejunum, accompanied with an increase in systemic (PBMCs) cytokine gene expression and a higher villous height in jejunum and ileum on day 30, while it was observed to be lower in jejunum on day 15 . 


\section{Methods}

Animals, housing, and experimental design

Current study was performed at the Veterinary Teaching Farm of the University of Murcia (Spain), using 72 piglets (Large White) weaned at $22 \pm 3$ days (d) of age with an average initial body weight (BW) of $5.53 \pm 1.19 \mathrm{~kg}$ and about 1:1 male:female ratio. Piglets were obtained from 12 different litters from sows with average parity of 3.43 . Without receiving any feed before weaning, after weaning all pigs were allotted visually trying to avoid great difference in weight among the animals in the same pen. Pens were randomly allotted to two treatments with 4 pens per treatment and 9 animals per pen (pen size: $0.61 \times 1.22 \mathrm{~m}$ ). Pigs were housed in an environmentally controlled unit $\left(25-27^{\circ} \mathrm{C}\right)$ with natural light throughout the experiment. The pens were full-slated (plastic slat) and contained one nipple drinker ad libitum and one feeder with 4 spaces. On day 4 post-weaning piglets were routinely vaccinated against PCV2 (Porcilis PCV-2, MSD) and no systematic medications were included in feed or water.

\section{Diets and additives}

A two-phase experimental diet was used, produced at a local feedmill (Pigalomar; Spain), without additional additives or medication but the dietary treatments reported (Table 8$)$. All diets were pelleted $(4 \mathrm{~mm})$ and were formulated to meet the current estimates for nutrient growth requirements for nursery pigs [74]. Diets did not contain spray-dried plasma, antibiotics, and pharmaceutical levels of zinc oxide. The dietary treatments consisted of a control diet and a treatment diet, being the control diet $+0.2 \%$ Fysal $^{\circledR}$ Solute (FS), a feed additive consisting of a blend of mannan-rich hydrolyzed copra meal and fermented rye with $A$. subrufescens. The feed additive used in the present experiment was provided by Trouw Nutrition, The Netherlands.

\section{Growth performance and sample collection}

Individual body weight of piglets was recorded at day 0 (weaning), day 15, day 30 and day 45, and average daily gain was calculated. At weaning (weaning $+18 \mathrm{~h}$ ), 10 control animals were sacrificed to obtain blood from the vena jugular and intestinal tissue samples as a basal treatment. Animals were euthanized by lethal intravenous injection with an overdose of tiobarbital IV $(50 \mathrm{mg} / \mathrm{kg}$ BW, Tiobarbital Braun Medical S.A., Barcelona, Spain). Subsequently, sacrification was done randomly at day 15 (control $n=11$, FS $n=10$ ), day 30 (control $n=6$, FS $\mathrm{n}=12$ ) and day 45 (control $\mathrm{n}=9$, FS $\mathrm{n}=13$ ) to obtain blood and intestinal tissue samples. Tissue samples were obtained from the jejunum (middle section), ileum $(5 \mathrm{~cm}$ adjacent to ileocecal valve), and colon (apex section of spiral) by three centimeter long gut sections, opened
Table 8 Composition of the experimental diets

\begin{tabular}{|c|c|c|}
\hline Item & $\begin{array}{l}\text { Phase } 1 \\
\text { Day 0-14 }\end{array}$ & $\begin{array}{l}\text { Phase } 2 \\
\text { Day } 15-45\end{array}$ \\
\hline \multicolumn{3}{|l|}{ Ingredients, \% } \\
\hline Barley & 29.98 & 25.00 \\
\hline Wheat & 24.00 & 26.89 \\
\hline Corn & 17.17 & 19.50 \\
\hline Soybean Meal 47 crude protein & 6.00 & 16.83 \\
\hline Ca carbonate & 0.45 & 0.61 \\
\hline Monocalcium phosphate & 0.75 & 0.78 \\
\hline Soybean oil & 3.50 & 3.67 \\
\hline Intestinal swine mucosal hydrolyzate ${ }^{1}$ & 2.50 & 0.00 \\
\hline Milkpowder & 5.00 & 0.00 \\
\hline Fysal MP² & 0.30 & 0.30 \\
\hline Salt & 0.30 & 0.44 \\
\hline L-Valine $(96.5 \%)$ & 0.050 & 0.025 \\
\hline DL-Methionine (99\%) & 0.175 & 0.175 \\
\hline L-Lysine HCl (98\%) & 0.542 & 0.525 \\
\hline L-Threonine (98\%) & 0.258 & 0.250 \\
\hline L-Tryptophan (98\%) & 0.033 & 0.008 \\
\hline Protein concentrate $^{3}$ & 6.00 & 2.00 \\
\hline Trouwmix 30 premix ${ }^{4}$ & 3.00 & 3.00 \\
\hline
\end{tabular}

${ }^{1}$ Protein source as hydrolysed peptides from porcine intestinal mucosa

${ }^{2}$ Blend of free and buffered organic acids (Formic, acetic, propionic acid)

${ }^{3}$ Gluten meal, extruded soybean meal, potato protein

${ }^{4}$ Vitamin and mineral premix provided the following per kilogram of diet: vitamin A, 15,000 IU; vitamin D, $2000 \mathrm{IU}$; vitamin E, $100 \mathrm{IU}$; $30 \mu \mathrm{g}$ of vitamin B12; vitamin K, 2 mg; D-pantothenicacid $15 \mathrm{mg}$ as calcium pantothenate; $30 \mathrm{mg}$ of nicotinicacid; choline, $150 \mathrm{mg}$ as betaine hydrchloride; $\mathrm{Mn}, 50 \mathrm{mg}$ as manganese oxide; $\mathrm{Zn}, 105 \mathrm{mg}$ as zinc oxide; $\mathrm{Fe}, 100 \mathrm{mg}$ as iron sulphate; $\mathrm{Cu}, 120 \mathrm{mg}$ as copper sulphate; I, $1.5 \mathrm{mg}$ as potassium iodide; $\mathrm{Se}, 0.42 \mathrm{mg}$ as sodium selenite; 6-phytase 1500 Phytase Unit (FTU)

along the mesenterial insertion and $2 \mathrm{~cm}$ cut from their middle section. After been gently washed in water, each sample was divided in two subsamples, one $(20 \mathrm{mg})$ was preserved in RNAlater (Life Technologies, USA) and one was fixed in $10 \%$ buffered formaldehyde and embedded in paraffin-wax for histomorphometrical and immunohistochemical studies. Blood samples were collected into ethylenediaminetetraacetic (EDTA) tubes (Vacutainer, Becton Dickinson, UK). Peripheral blood mononuclear cells (PBMCs) were isolated by Histopaque gradient and preserved in RNAlater (Life Technologies, USA) at $-80{ }^{\circ} \mathrm{C}$, after $24 \mathrm{~h}$ of refrigeration at $8{ }^{\circ} \mathrm{C}$, for subsequent gene expression analysis. Serum and plasma were isolated from whole blood by centrifugation (251 rcf, $10 \mathrm{~min}$ at room temperature) and preserved at $-80{ }^{\circ} \mathrm{C}$ up to analysis. 


\section{Sample analysis \\ Blood immunoglobulin analysis}

Total serum immunoglobulins IgA, IgE, IgG and IgM were quantified in an amount of $50 \mu \mathrm{L}$ serum sample by Enzyme Linked Immuno Sorbent Assay (ELISA) Porcine IgA (Immunoglobulin A) ELISA Kit E-EL-P1273; Porcine IgE (Immunoglobulin E) ELISA Kit E-EL-P0286; Porcine IgG (Immunoglobulin G) ELISA Kit E-EL-P0004; and Porcine IgM (Immunoglobulin M) ELISA Kit E-ELP2269 (Elabscience, USA) per manufacturer instructions. For establishment of the immunotype Th1/Th2, the cytokines IL-10 and IFN- $\gamma$ have been quantified in $50 \mu \mathrm{L}$ of serum sample by means of ELISA (Invitrogen, USA) as per manufacturer instructions.

\section{$B$ cells, $T$ cells and NK cells}

Flow cytometry was used to analyse subpopulations of different types of lymphocytes: B cells (CD45 + CD21+), $\mathrm{NK} \quad(\mathrm{CD} 45+\mathrm{CD} 3 \mathrm{e}-\mathrm{CD} 16+\mathrm{CD} 56+), \mathrm{T}$ lymphocytes (CD45+CD3e+), helper $\mathrm{T}$ lymphocytes (Th) (CD45+CD3e+CD4a+CD8a-), cytotoxic T lymphocytes $(\mathrm{Tc})(\mathrm{CD} 45+\mathrm{CD} 3 \mathrm{e}+\mathrm{CD} 4 \mathrm{a}-\mathrm{CD} 8 \mathrm{a}+)$. A sample of peripheral blood per tube was mixed with antibodies, using mouse anti-human CD56:RPE (clone MEM-188) (BioLegend, CA, USA), mouse anti-pig CD16:RPE (clone G7) and mouse anti-pig CD45:FITC (clone K252.1E4) (Bio-RAD, CA, USA), mouse anti-pig CD4a:PerCP-Cy5.5 (clone 74-12-4 or PT4), mouse anti-pig CD8a:PE (clone 76-2-11 or PT8), mouse anti-pig CD3e:PE-Cy7 (clone BB23-8E6-8C8) and mouse anti-human CD21:PE-Cy5 (clone B-ly4) (BD Pharmingen, Becton, Dickinson and Company, NJ, USA). Due to lack of porcine antibodies, human CD21 and CD56 were chosen based on crossreactivity and guaranty for use in pigs. CD45 was used to differentiate the population of lymphocytes from the rest of the leukocytes (monocytes and granulocytes). Two tubes were prepared per sample, with tube 1 containing $50 \mu \mathrm{L}$ of peripheral blood with $5 \mu \mathrm{L}$ CD 45 and $2.5 \mu \mathrm{L} \mathrm{CD} 3, \mathrm{CD} 8$ and CD4. Tube 2 contained $50 \mu \mathrm{L}$ of peripheral blood with $5 \mu \mathrm{L}$ CD45 and CD16, $2.5 \mu \mathrm{L}$ CD3 and CD56 and $10 \mu \mathrm{L} \mathrm{CD} 21$. After mixing and $15 \mathrm{~min}$ of incubation, the sample was lysed with a $0.5 \mathrm{ml}$ lysin solution (FACS LYSING, Becton, Dickinson and Company, NJ, USA). After mixing and $15 \mathrm{~min}$ of incubation, the sample was analysed in the FC500 cytometer (Beckman Coulter, IN, USA) by using a single $488 \mathrm{~nm}$ (blue) laser and obtaining analysis matrices for each analyte.

\section{Immunohistochemistry for levels of IgA producing cells}

In jejunum, ileum and colon tissue IgA secretory cells were detected using the avidin-biotine-peroxidase complex technique. From the samples embedded in paraffin-wax $5 \mu \mathrm{m}$ thick slides were obtained, dewaxed and dehydrated with graded ethanol and the endogenous peroxidase activity was quenched in $3 \% \mathrm{H}_{2} \mathrm{O}_{2}$ in methanol for $30 \mathrm{~min}$. Samples were treated with $10 \%$ pronase in TBS (Sigma-Aldrich, USA) for antigen retrieval (12 min). After pretreatment, samples were rinsed three times in TBS for $5 \mathrm{~min}$ each and incubated for $30 \mathrm{~min}$ with 100 $\mu \mathrm{L}$ of blocking solution per slide at room temperature in a humid chamber, before incubation for $1 \mathrm{~h}$ at $37^{\circ} \mathrm{C}$ with the primary antibody goat anti-pig IgA (A100-102, Bethyl, USA) diluted 1:3000 in TBS. The secondary antibody biotin conjugate rabbit anti-goat Ab (Dako, USA) diluted 1:300 in TBS was incubated for $30 \mathrm{~min}$ at room temperature. The Vectastain ${ }^{\circledR}$ Elite ABC kit (Vector, USA) was applied for $1 \mathrm{~h}$ at room temperature. Positive labeling was detected using 3,3'-diaminobenzidine tetrahydrochloride (Dako, USA). Sections were counterstained with Mayer's haematoxylin, dehydrated and mounted.By using a Zeiss Axioskop 40 microscope (Carl Zeiss, Oberkochen, Germany) with a Spot Insight camera and the Spot Advanced software (Spot Imaging Solution, Michigan, USA) the number of IgA secretory cells in the intestinal lamina propria was counted. Immunolabeled cells were counted in 10 non-overlapping consecutive high magnification fields of $25.000 \mu \mathrm{m}^{2}$.

\section{Cytokine gene expression}

Gene expression for cytokines IFN- $\alpha$, IFN- $\gamma$, IL- $1 \alpha$, IL-1 $\beta$, IL-6, IL-8, IL-10, IL-12p35 (IL-12 $\alpha$ ), IL-12p40 (IL-12 $\beta$ ), TNF- $\alpha$, and TGF- $\beta$ was analysed using relative quantification, with primers previously described in literature (see Table 9). Total RNA was isolated from tissue and PBMCs samples by means of Micro RNeasy kit (Qiagen, USA) and DNAc was synthetized using the Geneamp RNA PCR Core Kit (Life Technology, USA). The PCRs were performed using a 7300 ABI thermocycler (Life Technologies, USA) and the GoTaq ${ }^{\circledR}$ qPCR Master Mix (Promega, USA) with SYBR-Green chemistry. The specificity of the reaction was assessed by analyzing the melting curve. The samples were normalized using the average $\mathrm{Ct}$ for glyceraldehyde-3-phosphatedehydrogenase (GAPDH), cyclophilin and $\beta$-Actin. The expression for each sample was calculated [84], correcting to the PCRs efficiency, calculated by serial decimal dilutions and using the slope offered by the thermacycler software, and used as control group the animals sampled at day 0. The efficiency of q-PCRs was between 91 and $105 \%$. Data were expressed as fold change, normalized to the lowest value (value $=1$ ).

\section{Intestinal histomorphometry}

Five photomicrographs were taken with a Zeiss Axiocam 503 color (Carl Zeiss, Oberkochen, Germany) coupled to a Zeiss Axioskop 40 microscope (Carl Zeiss, 
Table 9 Primers of the cytokines IFN- $a$, IFN- $\gamma$, IL-1a, IL-1 $\beta, I L-6, I L-8, I L-10, I L-12 p 35$ (IL-12a), IL-12p40 (IL-12 $\beta$ ), TNF-a and TGF- $\beta$ and primers of glyceraldehyde-3-phosphatedehydrogenase (GAPDH), cyclophilin and $\beta$-actin

\begin{tabular}{|c|c|c|c|}
\hline & Primer forward $\left(5^{\prime} \rightarrow 3^{\prime}\right)$ & Primer reverse $\left(5^{\prime} \rightarrow 3^{\prime}\right)$ & References \\
\hline IFN-a & 5'-CCCCTGTGCCTGGGAGAT-3' & 5'-AGGTTTCTGGAGGAAGAGAAGGA-3' & [75] \\
\hline $\mathrm{IFN}-\gamma$ & 5'-TGGTAGCTCTGGGAAACTGAATG-3' & 5'-GGCTTTGCGCTGGATCTG-3' & [76] \\
\hline IL-1a & 5'-GTGCTCAAAACGAAGACGAACC-3' & 5'-CATATTGCCATGCTTTTCCCAGAA-3' & [77] \\
\hline$I L-1 \beta$ & 5'-AACGTGCAGTCTATGGAGT-3' & 5'-GAACACCACTTCTCTCTTCA-3' & [78] \\
\hline IL-6 & 5'-CTGGCAGAAAACAACCTGAACC-3' & 5'-TGATTCTCATCAAGCAGGTCTCC-3' & [78] \\
\hline IL-8 & 5'-GCTCTCTGTGAGGCTGCAGTTC-3' & 5'-AAGGTGTGGAATGCGTATTTATGC-3' & [79] \\
\hline $\mid \mathrm{LL}-10$ & 5'-TGAGAACAGCTGCATCCACTTC-3' & 5'-TCTGGTCCTTCGTTTGAAAGAAA-3' & [77] \\
\hline IL-12p35 & 5'-AGTTCCAGGCCATGAATGCA-3' & 5'-TGGCACAGTCTCACTGTTGA-3' & [75] \\
\hline IL-12p40 & 5'-TTTCAGACCCGACGAACTCT-3' & 5'-CATTGGGGTACCAGTCCAAC-3' & {$[80]$} \\
\hline TNF- $a$ & 5'-ACTCGGAACCTCATGGACAG-3' & 5'-AGGGGTGAGTCAGTGTGACC-3' & [81] \\
\hline TGF- $\beta$ & 5'-CACGTGGAGCTATACCAGAA-3' & 5'-TCCGGTGACATCAAAGGACA-3' & [76] \\
\hline$\beta$-actin & 5'-CTACGTCGCCCTGGACTTC-3' & 5'-GATGCCGCAGGATTCCAT-3' & {$[82]$} \\
\hline Cyclophilin & 5'-TGCTTTCACAGAATAATTCCAGGATTTA-3' & 5'-GACTTGCCACCAGTGCCATTA-3' & [83] \\
\hline GAPDH & 5'-ACATGGCCTCCAAGGAGTAAGA-3' & 5'-GATCGAGTTGGGGCTGTGACT-3' & [83] \\
\hline
\end{tabular}

Oberkochen, Germany) with $10 \times$ magnification, from each section of jejunum and ileum. Both the height of the villous (tip to villous-crypt junction) and depth of the crypt (from villous-crypt junction to the base of villous) were analysed with the ZEISS Efficient Navigation software (Carl Zeiss, Oberkochen, Germany), according to manufacturer instruction. Randomly selected well-oriented intact villi and crypts $(\mathrm{n}=10)$ were measured per piglet, per timepoint for jejunal and ileal tissue. The mean villous height and crypt depth of each intestinal tissue was calculated and by dividing villous height by crypt depth the villous height/crypt depth ratio was calculated. All morphometric measurements were performed by the same blinded to treatments researcher.

\section{Statistical analysis}

Data were analyzed using the MIXED procedure of SAS (version 9.4, SAS Institute; Cary, USA). The cytokine gene expression data was transformed as $\log 2$ of the value for normalization. The model included the fixed effects of treatment. Animal was the experimental unit. Statistical significance and tendency were considered at $P \leq 0.05$ and $0.05 \leq P \leq 0.10$, respectively.

\section{Supplementary Information}

The online version contains supplementary material available at https://doi. org/10.1186/s40813-021-00241-y.
Additional file 1. Appendix. Table 1. Effects of treatment ${ }^{1}$ on cytokine expression in jejunum, ileum and colon tissue of piglets at day 15. Table 2 . Effects of treatment ${ }^{1}$ on cytokine expression in jejunum, ileum and colon tissue and PBMC of piglets at day 30. Table 3. Effects of treatment on cytokine expression in jejunum, ileum and colon tissue of piglets at day 45.

\section{Acknowledgements}

The authors would like to thank Marc Jacobs (Trouw Nutrition R\&D, The Netherlands) and Javier Roques Mata (Trouw Nutrition Spain) for their contributions to this article.

\section{Authors' contributions}

NG analyzed and interpreted the data and prepared first draft of the manuscript and was the major contributor in writing. GR, FF and CCG performed the DNA extraction, QPCR analysis and the histological examination of jejunum. LF contributed to reviewing the manuscript. All authors read and approved the final manuscript.

\section{Funding}

This work was funded by Trouw Nutrition B.V. (a Nutreco N.V. company) for University of Murcia to conduct the animal trial, data collection and sample analysis.

Availability of data and materials

The datasets supporting the conclusions of this article are included within the article (and its Additional file 1 (Appendix).

\section{Declarations}

\section{Ethics approval and consent to participate}

All the experimental procedures described in this research were reviewed and approved by the Bioethical Committee of the University of Murcia and applied under project license permit CEEA-OH 465/2018.

\section{Consent for publication}

Not applicable. 


\section{Competing interests}

The authors have declared that no competing interest exists.

\section{Author details}

${ }^{1}$ Trouw Nutrition Innovation, Amersfoort 3811 MH, The Netherlands. ${ }^{2}$ Instituto de Inmunología Clínica y Enfermedades Infecciosas, Málaga, Spain. ${ }^{3}$ Dpto. Producción Animal, Facultad de Veterinaria, Universidad de Murcia, Murcia, Spain. ${ }^{4}$ Dpto. Anatomía y Anatomía Patológica Comparadas, Universidad de Murcia, Murcia, Spain.

Received: 14 July 2021 Accepted: 2 December 2021

\section{Published online: 09 December 2021}

\section{References}

1. Burkey TE, Skjolaas KA, Minton JE. BOARD-invited review: porcine mucosal immunity of the gastrointestinal tract1. J Anim Sci. 2009. https:// doi.org/10.2527/jas.2008-1330.

2. Cerutti $A$, Rescigno $M$. The biology of intestinal immunoglobulin $A$ responses. Immunity. 2008. https://doi.org/10.1016/j.immuni.2008.05.001.

3. Gutzeit C, Magri G, Cerutti A. Intestinal IgA production and its role in hostmicrobe interaction. Immunol Rev. 2014. https://doi.org/10.1111/imr. 12189

4. Pié S, Lallès JP, Blazy F, Laffitte J, Sève B, Oswald IP. Weaning is associated with an upregulation of expression of inflammatory cytokines in the intestine of piglets. J Nutr. 2004. https://doi.org/10.1093/jn/134.3.641.

5. de Groot N, Fariñas F, Cabrera-Gómez CG, Pallares FJ, Ramis G. Weaning causes a prolonged but transient change in immune gene expression in the intestine of piglets. J Anim Sci. 2021. https://doi.org/10.1093/jas/ skab065/6153447.

6. Spreeuwenberg MAM, Verdonk JMAJ, Gaskins HR, Verstegen MWA. Small intestine epithelial barrier function is compromised in pigs with low feed intake at weaning. J Nutr. 2001. https://doi.org/10.1093/jn/131.5.1520.

7. Moeser AJ, Pohl CS, Rajput M. Weaning stress and gastrointestinal barrier development: implications for lifelong gut health in pigs. Anim Nutr 2017. https://doi.org/10.1016/j.aninu.2017.06.003.

8. McCracken BA, Gaskins HR, Ruwe-Kaiser PJ, Klasing KC, Jewell DE. Dietdependent and diet-independent metabolic responses underlie growth stasis of pigs at weaning. J Nutr. 1995. https://doi.org/10.1093/jn/125.11. 2838

9. Schachtschneider KM, Yeoman CJ, Isaacson RE, White BA, Schook LB, Pieters M. Modulation of systemic immune responses through commensal gastrointestinal microbiota. PLoS ONE. 2013. https://doi.org/10.1371/ journal.pone.0053969.

10. Gresse R, Chaucheyras-Durand F, Fleury MA, Van de Wiele T, Forano E, Blanquet-Diot S. Gut microbiota dysbiosis in postweaning piglets: understanding the keys to health. Trends Microbiol. 2017. https://doi.org/10. 1016/j.tim.2017.05.004.

11. Pluske JR, Turpin DL, Kim JC. Gastrointestinal tract (gut) health in the young pig. Anim Nutr. 2018. https://doi.org/10.1016/j.aninu.2017.12.004

12. Jayaraman B, Nyachoti CM. Husbandry practices and gut health outcomes in weaned piglets: a review. Anim Nutr. 2017. https://doi.org/10. 1016/j.aninu.2017.06.002.

13. Pluske JR, Kim JC, Black JL. Manipulating the immune system for pigs to optimise performance. Anim Prod Sci. 2018. https://doi.org/10.1071/ AN17598.

14. Superchi P, Saleri R, Borghetti P, De Angelis E, Ferrari L, Cavalli V, et al. Effects of dietary nucleotide supplementation on growth performance and hormonal and immune responses of piglets. Animal. 2012. https:// doi.org/10.1017/S1751731111002473.

15. Wisitrassameewong K, Karunarathna SC, Thongklang N, Zhao R, Callac $P$, Moukha S, et al. Agaricus subrufescens: a review. Saudi J Biol Sci. 2012 https://doi.org/10.1016/j.sjbs.2012.01.003.

16. Ariandi $Y$, Meryandi A. Enzymatic hydrolysis of copra meal by mannanase from Streptomyces sp. BF3.1 for the production of mannooligosaccharides. Hayati J Biosci. 2015. https://doi.org/10.4308/hjb.22.2.79.

17. Kawagishi H, Inagaki R, Kanao T, Mizuno T, Shimura K, Ito H, et al. Fractionation and antitumor activity of the water-in-soluble residue of Agaricus blazei fruiting bodies. Carbohydr Res. 1989. https://doi.org/10. 1016/0008-6215(89)84040-6.
18. Itoh $\mathrm{H}$, Amano $\mathrm{H}$, Noda $\mathrm{H}$, Ito $\mathrm{H}$. Inhibitory action of a $(1 \rightarrow 6)$ B-D-glucanprotein complex (FIE-2-b) isolated from Agaricus blazei Murill ("Himematsutake") on Meth A fibrosarcoma-bearing mice and its antitumor mechanism. Jpn J Pharmacol. 1994. https://doi.org/10.1254/jjp.66.265.

19. Ohno N, Furukawa M, Miura NN, Adachi Y, Motoi M, Yadomae T. Antitumor $\beta$-glucan from the cultured fruit body of Agaricus blazei. Biol Pharm Bull. 2001;24(7):820-8.

20. Akramienè D, Kondrotas A, Didžiapetrienè J, Kèvelaitis E. Effects of B-glucans on the immune system. Medicina (B Aires). 2007. https://doi. org/10.1248/bpb.24.820.

21. Smiderle FR, Ruthes AC, van Arkel J, Chanput W, lacomini M, Wichers $\mathrm{HJ}$, et al. Polysaccharides from Agaricus bisporus and Agaricus brasiliensis show similarities in their structures and their immunomodulatory effects on human monocytic THP-1 cells. BMC Complement Altern Med. 2011. https://doi.org/10.1186/1472-6882-11-58.

22. Niewold TA. Intestinal health: key to maximise growth performance in livestock. Wageningen Academic Publishers; 2015. https://doi.org/10. 3920/978-90-8686-792-9.

23. Mosmann TR, Coffman RL. TH1 and TH2 cells: different patterns of lymphokine secretion lead to different functional properties. Annu Rev Immunol. 1989. https://doi.org/10.1146/annurev.iy.07.040189.001045.

24. Murtaugh MP, Baarsch MJ, Zhou Y, Scamurra RW, Lin G. Inflammatory cytokines in animal health and disease. Vet Immunol Immunopathol. 1996. https://doi.org/10.1016/S0165-2427(96)05698-X.

25. McClane SJ, Rombeau JL. Cytokines and inflammatory bowel disease: a review. J Parenter Enter Nutr. 1999. https://doi.org/10.1177/0148607199 02300506.

26. Oswald IP, Dozois CM, Barlagne R, Fornout S, Johanse MV, Bogh HO. Cytokine mRNA expression in pigs infected with Schistosoma japonicum. Parasitology. 2001. https://doi.org/10.1017/S0031182001007399.

27. McKay DM, Baird AW. Cytokine regulation of epithelial permeability and ion transport. Gut. 1999. https://doi.org/10.1136/gut.44.2.283.

28. Maribo H. Agaricus and Rød Solhat for weaners. Natl Comm Pig Prod. 2004.

29. Zhang L, Shen H, Wang S, Fang G, Qiu H, Feng Y, Dong Z. Effects of submerged fermentation products of Agaricus blazei Murill on digestion and immunity for Weaned Piglets. Fujian J Agric Sci. 2008;23:31-4.

30. Shen H, Chen J, Wu L, Li Y, Zhou T. Biodegrading wheat bran with Agaricus blazei and its effects on intestinal development identified with mice. J Integr Agric. 2012. https://doi.org/10.1016/S2095-3119(12)60031-8.

31. Montagne L, Pluske J, Hampson D. A review of interactions between dietary fibre and the intestinal mucosa, and their consequences on digestive health in young non-ruminant animals. Anim Feed Sci Technol. 2003. https://doi.org/10.1016/S0377-8401(03)00163-9.

32. Pluske JR, Williams IH, Aherne FX. Maintenance of villous height and crypt depth in piglets by providing continuous nutrition after weaning. Anim Sci. 1996. https://doi.org/10.1017/S1357729800014417.

33. Shirkey TW, Siggers RH, Goldade BG, Marshall JK, Drew MD, Laarveld $B$, et al. Effects of commensal bacteria on intestinal morphology and expression of proinflammatory cytokines in the gnotobiotic pig. Exp Biol Med. 2006. https://doi.org/10.1177/153537020623100807.

34. Gelberg HB, Mcgavin MD, Zachary JF. Pathologic basis of veterinary disease 2007. p. 301-391

35. Cera KR, Mahan DC, Cross RF, Reinhart GA, Whitmoyer RE. Effect of age, weaning and postweaning diet on small intestinal growth and jejunal morphology in young swine. J Anim Sci. 1988. https://doi.org/10.2527/ jas1988.662574x.

36. Adeola O, King DE. Developmental changes in morphometry of the small intestine and jejunal sucrase activity during the first nine weeks of postnatal growth in pigs1. J Anim Sci. 2006. https://doi.org/10.2527/2006 841112x.

37. Tsukahara T, Inoue R, Nakatani M, Fukuta K, Kishino E, Ito T, et al. Influence of weaning age on the villous height and disaccharidase activities in the porcine small intestine. Anim Sci J. 2016. https://doi.org/10.1111/asj. 12399

38. Edfors-Lilja I, Wattrang E, Magnusson U, Fossum C. Genetic variation in parameters reflecting immune competence of swine. Vet Immunol Immunopathol. 1994. https://doi.org/10.1016/0165-2427(94)90011-6.

39. Clapperton M, Glass EJ, Bishop SC. Pig peripheral blood mononuclear leucocyte subsets are heritable and genetically correlated with performance. Animal. 2008. https://doi.org/10.1017/S1751731108002929. 
40. Clapperton M, Diack AB, Matika O, Glass EJ, Gladney CD, Mellencamp MA, et al. Traits associated with innate and adaptive immunity in pigs: heritability and associations with performance under different health status conditions. Genet Sel Evol. 2009. https://doi.org/10.1186/ 1297-9686-41-54.

41. García GR, Dogi CA, Ashworth GE, Berardo D, Godoy G, Cavaglieri LR, et al. Effect of breast feeding time on physiological, immunological and microbial parameters of weaned piglets in an intensive breeding farm. Vet Immunol Immunopathol. 2016. https://doi.org/10.1016/j.vetimm. 2016.02.009.

42. Chan Y, Chang T, Chan CH, Yeh YC, Chen CW, Shieh B, et al. Immunomodulatory effects of Agaricus blazei Murill in Balb/cByJ mice. J Microbiol Immunol Infect. 2007; PBMID: 17639159.

43. Kasai H, He LM, Kawamura M, Yang PT, Deng XW, Munkanta M, et al. IL-12 production induced by Agaricus blazei fraction $\mathrm{H}(\mathrm{ABH})$ involves toll-like receptor (TLR). Evidence-based complement. Altern Med. 2004. https:// doi.org/10.1093/ecam/neh043.

44. Kaneno R, Fontanari LM, Santos SA, Di Stasi LC, Rodrigues Filho E, Eira AF. Effects of extracts from Brazilian sun-mushroom (Agaricus blazei) on the NK activity and lymphoproliferative responsiveness of Ehrlich tumorbearing mice. Food Chem Toxicol. 2004. https://doi.org/10.1016/j.fct. 2004.01.014.

45. Yuminamochi E, Koike T, Takeda K, Horiuchi I, Okumura K. Interleukin-12and interferon- $\gamma$-mediated natural killer cell activation by Agaricus blazei Murill. Immunology. 2007. https://doi.org/10.1111/j.1365-2567.2006. 02558.x.

46. Riggi SJ, Di Luzio NR. Identification of a reticuloendothelial stimulating agent in zymosan. Am J Physiol Content. 1961. https://doi.org/10.1152/ ajplegacy.1961.200.2.297.

47. Bogwald J, Johnson E, Seljelid R. The cytotoxic effect of mouse macrophages stimulated in vitro by a beta-1,3-d-glucan from yeast cell walls. Scand J Immunol. 1982. https://doi.org/10.1111/j.1365-3083.1982.tb006 52.x.

48. Hetland G, Sandven P. Beta-1,3-glucan reduces growth of Mycobacterium tuberculosis in macrophage cultures. FEMS Immunol Med Microbiol. 2002. https://doi.org/10.1111/j.1574-695X.2002.tb00570.x.

49. Morikawa K, Takeda R, Yamazaki M, Mizuno D. Induction of tumoricidal activity of polymorphonuclear leukocytes by a linear beta-1,3-D-glucan and other immunomodulators in murine cells. Cancer Res. 1985; PMID: 3156669.

50. Amino M, Noguchi R, Yata J, Matsumura J, Hirayama R, Abe O, et al. Studies on the effect of lentinan on human immune system. II. In vivo effect on NK activity, MLR induced killer activity and PHA induced blastic response of lymphocytes in cancer patients. Gan To Kagaku Ryoho. 1983; PMID: 6225393.

51. Ibuki M, Fukui K, Kanatani H, Mine Y. Anti-inflammatory effects of mannanase-hydrolyzed copra meal in a porcine model of colitis. J Vet Med Sci. 2014. https://doi.org/10.1292/jvms.13-0424.

52. Choi EY, Lee SS, Hyeon JY, Choe SH, Keum BR, Lim JM, et al. Effects of $\beta$-Glucan on the release of nitric oxide by macrophages stimulated with Lipopolysaccharide, Asian-Australasian. J Anim Sci. 2016. https://doi.org/ 10.5713/ajas.16.0418.

53. Kogan G, Kocher A. Role of yeast cell wall polysaccharides in pig nutrition and health protection. Livest Sci. 2007. https://doi.org/10.1016/j.livsci. 2007.01.134.

54. Kim K, Ehrlich A, Perng V, Chase JA, Raybould H, Li X, et al. Algae-derived $\beta$-glucan enhanced gut health and immune responses of weaned pigs experimentally infected with a pathogenic E. coli. Anim Feed Sci Technol. 2019. https://doi.org/10.1016/j.anifeedsci.2018.12.004.

55. McCracken BA, Spurlock ME, Roos MA, Zuckermann FA, Gaskins HR. Weaning anorexia may contribute to local inflammation in the piglet small intestine. J Nutr. 1999. https://doi.org/10.1093/jn/129.3.613.

56. Kramer DR, Sutherland RM, Bao S, Husband AJ. Cytokine mediated effects in mucosal immunity. Immunol Cell Biol. 1995. https://doi.org/10.1038/ icb.1995.61.

57. Ramsay AJ. Genetic approaches to the study of cytokine regulation of mucosal immunity. Immunol Cell Biol. 1995. https://doi.org/10.1038/icb. 1995.78.

58. Stadnyk AW. Cytokine production by epithelial cells 1. FASEB J. 1994. https://doi.org/10.1096/fasebj.8.13.7926369.
59. Jung HC, Eckmann L, Yang SK, Panja A, Fierer J, Morzycka-Wroblewska E, et al. A distinct array of proinflammatory cytokines is expressed in human colon epithelial cells in response to bacterial invasion. J Clin Invest. 1995. https://doi.org/10.1172/JCl117676.

60. Pluske JR, Pethick DW, Hopwood DE, Hampson DJ. Nutritional influences on some major enteric bacterial diseases of pig. Nutr Res Rev. 2002. https://doi.org/10.1079/nrr200242.

61. Kelly D, Begbie R, King TP. Nutritional influences on interactions between bacteria and the small intestinal mucosa. Nutr Res Rev. 1994. https://doi. org/10.1079/nrr19940013.

62. Wang S, Wang J, Mou H, Luo B, Jiang X. Inhibition of Adhesion of Intestinal Pathogens (Escherichia coli, Vibrio cholerae, Campylobacter jejuni, and Salmonella Typhimurium) by common oligosaccharides. Foodborne Pathog Dis. 2015. https://doi.org/10.1089/fpd.2014.1835.

63. Oyofo BA, DeLoach JR, Corrier DE, Norman JO, Ziprin RL, Mollenhauer $\mathrm{HH}$. Prevention of Salmonella typhimurium colonization of broilers with D-mannose. Poult Sci. 1989. https://doi.org/10.3382/ps.0681357.

64. Spring P, Wenk C, Dawson KA, Newman KE. The effects of dietary mannaoligosaccharides on cecal parameters and the concentrations of enteric bacteria in the ceca of salmonella-challenged broiler chicks. Poult Sci. 2000. https://doi.org/10.1093/ps/79.2.205.

65. Fabà L, Litjens R, Allaart J, Van Den Hil PR. Feed additive blends fed to nursery pigs challenged with Salmonella. J Anim Sci. 2020. https://doi. org/10.1093/jas/skz382.

66. de Groot N, Faba L, Roubos-van der Hil P. Competitive exclusion by promoting growth of beneficial bacteria after Salmonella infection. In: Proceeding. Vol. 10, advances in animal biosciences-manipulating pig production XVII. Adelaide; 2019. p s51.

67. Solano-Aguilar Gl, Jang S, Lakshman S, Gupta R, Beshah E, Sikaroodi M, et al. The effect of dietary mushroom Agaricus bisporus on intestinal microbiota composition and host immunological function. Nutrients. 2018. https://doi.org/10.3390/nu10111721.

68. Meehan CJ, Beiko RG. A phylogenomic view of ecological specialization in the lachnospiraceae, a family of digestive tract-associated bacteria. Genome Biol Evol. 2014. https://doi.org/10.1093/gbe/evu050.

69. Pinto AV, Martins PR, Romagnoli GG, Campanelli AP, Terezan AP, Filho ER, et al. Polysaccharide fraction of Agaricus brasiliensis avoids tumor-induced IL-10 production and changes the microenvironment of subcutaneous Ehrlich adenocarcinoma. Cell Immunol. 2009. https://doi.org/10.1016/j. cellimm.2009.01.002

70. Sorimachi K, Akimoto K, Ikehara Y, Inafuku K, Okubo A, Yamazaki S. Secretion of TNF-a, IL-8 and nitric oxide by macrophages activated with Agaricus blazei Murill fractions in vitro. Cell Struct Funct. 2001. https://doi. org/10.1247/csf.26.103.

71. Førland DT, Johnson E, Sætre L, Lyberg T, Lygren I, Hetland G. Effect of an extract based on the medicinal mushroom Agaricus blazei Murill on expression of cytokines and calprotectin in patients with ulcerative colitis and Crohn's disease. Scand J Immunol. 2011. https://doi.org/10.1111/j. 1365-3083.2010.02477.x.

72. Strober W, Fuss IJ. Proinflammatory cytokines in the pathogenesis of inflammatory bowel diseases. Gastroenterology. 2011. https://doi.org/10. 1053/j.gastro.2011.02.016.

73. Friedrich M, Pohin M, Powrie F. Cytokine networks in the pathophysiology of inflammatory bowel disease. Immunity. 2019. https://doi.org/10.1016/j. immuni.2019.03.017.

74. Nutrient Requirements of Swine. Washington, D.C.: National Academies Press; 1998. Available from: http://www.nap.edu/catalog/6016.

75. Moue M, Tohno M, Shimazu T, Kido T, Aso H, Saito T, et al. Toll-like receptor 4 and cytokine expression involved in functional immune response in an originally established porcine intestinal epitheliocyte cell line. Biochim Biophys Acta Gen Subj. 2008. https://doi.org/10.1016/j.bbagen.2007.11. 006.

76. Royaee AR, Husmann RJ, Dawson HD, Calzada-Nova G, Schnitzlein WM, Zuckermann FA, et al. Deciphering the involvement of innate immune factors in the development of the host response to PRRSV vaccination. Vet Immunol Immunopathol. 2004. https://doi.org/10.1016/j.vetimm. 2004.09.018.

77. Verpoest S, Cay B, Favoreel H, De Regge N. Age-dependent differences in Pseudorabies virus neuropathogenesis and associated cytokine expression. J Virol. 2017. https://doi.org/10.1128/jvi.02058-16. 
78. Borca MV, Gudmundsdottir I, Fernández-Sainz IJ, Holinka LG, Risatti GR. Patterns of cellular gene expression in swine macrophages infected with highly virulent classical swine fever virus strain Brescia. Virus Res. 2008. https://doi.org/10.1016/j.virusres.2008.08.009.

79. Bracarense APFL, Lucioli J, Grenier B, Drociunas Pacheco G, Moll W-D, Schatzmayr G, et al. Chronic ingestion of deoxynivalenol and fumonisin, alone or in interaction, induces morphological and immunological changes in the intestine of piglets. Br J Nutr. 2012. https://doi.org/10. 1017/S0007114511004946.

80. Kim CJ, Kovacs-Nolan JA, Yang C, Archbold T, Fan MZ, Mine Y. I-Tryptophan exhibits therapeutic function in a porcine model of dextran sodium sulfate (DSS)-induced colitis. J Nutr Biochem. 2010. https://doi.org/10. 1016/j.jnutbio.20.

81. Gabler NK, Spencer JD, Webel DM, Spurlock ME. n-3 PUFA attenuate lipopolysaccharide-induced down-regulation of toll-like receptor 4 expression in porcine adipose tissue but does not alter the expression of other immune modulators. J Nutr Biochem. 2008. https://doi.org/10. 1016/j.jnutbio.2006.11.014.

82. Skovgaard K, Mortensen S, Boye M, Poulsen KT, Campbell FM, Eckersall PD, et al. Rapid and widely disseminated acute phase protein response after experimental bacterial infection of pigs. Vet Res. 2009. https://doi. org/10.1051/vetres/2009006.

83. Duvigneau JC, Hartl RT, Groiss S, Gemeiner M. Quantitative simultaneous multiplex real-time PCR for the detection of porcine cytokines. I Immunol Methods. 2005. https://doi.org/10.1016/j.jim.2005.06.021.

84. Pfaff MW. A new mathematical model for relative quantification in realtime RT-PCR. Nucleic Acids Res. 2001. https://doi.org/10.1093/nar/29.9. e45.

\section{Publisher's Note}

Springer Nature remains neutral with regard to jurisdictional claims in published maps and institutional affiliations.

- fast, convenient online submission

- thorough peer review by experienced researchers in your field

- rapid publication on acceptance

- support for research data, including large and complex data types

- gold Open Access which fosters wider collaboration and increased citations

- maximum visibility for your research: over $100 \mathrm{M}$ website views per year

At BMC, research is always in progress.

Learn more biomedcentral.com/submissions 